\title{
MENINGKATKAN KEMAMPUAN MENULIS TEKS EKSPLANASI DENGAN MENGGUNAKAN MEDIA GAMBAR BERSERI PADA SISWA KELAS VII
}

\author{
Novi Salfera
}

SMPN 1 Banuhampu

\begin{abstract}
Abstrak
Sebagian besar siswa belum mampu mengungkapkan gagasannya melalui menulis teks eksplanasi. Salah satu cara untuk mengatasi masalah tersebut dengan menggunakan media gambar berseri. Rumusan masalah dalam penelitian ini adalah bagaimanakah penggunaan gambar berseri dapat meningkatkan kemampuan menulis teks eksplanasi? Tujuan penelitian ini untuk meningkatkan kemampuan menulis teks eksplanasi dengan menggunakan media gambar berseri. Penelitian ini menggunakan penelitian tindakan kelas dengan dua siklus. Setiap siklus dilaksanakan selama dua kali pertemuan. Subjek penelitian adalah siswa kelas VII 8 SMPN 1 Banuhampu yang berjumlah 31 orang. Hasil penelitian menunjukkan bahwa terjadinya peningkatan kemampuan siswa dalam menulis teks eksplanasi. Peningkatan kemampuan siswa itu terlihat dalam mengungkapkan isi tulisan, struktur, kosakata, kalimat dan mekaniknya. Ini membuktikan bahwa gambar berseri cocok digunakan dalam pembelajaran menulis teks eksplanasi. Saran yang dapat diberikan berkaitan dengan penelitian ini adalah guru harus memberikan banyak latihan eksplanasi, membuat jadwal kegiatan ekstrakurikuler yang berkaitan dengan menulis teks eksplanasi.
\end{abstract}

Kata kunci: menulis, teks eksplanasi, gambar berseri

\section{PENDAHULUAN}

Pembelajaran Bahasa Indonesia dalam kurikulum 2013, salah satunya menggunakan model pembelajaran berbasis teks. Hal ini sesuai materi siswa kelas VII dengan Kompetensi Dasar 3.2 Membedakan teks hasil observasi, tanggapan deskriptif, eksposisi, eksplanasi, dan cerita pendek baik melalui lisan maupun tulisan dan 4.2 Menyusun teks hasil observasi, tanggapan deskriptif, eksposisi, eksplanasi, dan cerita pendek sesuai dengan karakteristik teks yang akan dibuat baik secara lisan maupun tulisan. Siswa SMPN 1 Banuhampu khususnya kelas VII, sebagai pilot proyek pelaksanaaan kurikulum 2013, diharapkan mempunyai kemampuan membedakan dan menyajikan gagasan dalam bentuk teks yang sesuai sehingga memudahkan orang lain memahami gagasan yang ingin disampaikan. 
Kenyataan yang ditemui di kelas VII 8 di SMPN 1 Banuhampu sebagian besar siswanya belum mampu mengungkapkan gagasannya melalui teks eksplanasi. Berbeda jika siswa ditugaskan mengidentifikasi struktur teks berdasarkan teks yang sudah ada. Mereka tidak mengalami kesulitan saat menempatkan teks ke dalam struktur teks eksplanasi; pernyataan umum, deretan penjelasan (eksplanasi) dan interpretasi. Namun ketika siswa ditugaskan menulis teks eksplanasi dengan kata-kata sendiri, mereka masih mengalami kesulitan.

Rendahnya keterampilan menulis teks eksplanasi siswa diindikasikan oleh kurangnya kemampuan siswa dalam mengorganisasikan ide dengan baik, pengembangan kerangka karangan, dan penyusunan kalimat serta kosakata yang digunakan masih terbatas. Mereka masih belum memahami penggunaan ejaan yang benar. Dari hasil pengamatan permasalahan yang muncul saat siswa ditugaskan menulis teks eksplanasi adalah antara lain:1. siswa membutuhkan waktu yang lama untuk menulis karangan teks eksplanasi. 2. Siswa kurang mampu menggunakan dan memilih kata dalam menuangkan buah pikirannya, sering mengulang kata "lalu" dan "terus". 3. Isi kalimat relatif tidak menggambarkan topik. 4. Kalimat yang satu dengan kalimat yang lain tidak berkesinambungan, paragraf yang satu dengan paragraf yang lain tidak koheren. Masalah rendahnya keterampilan menulis teks eksplanasi siswa juga dipengaruhi oleh kurangnya media yang digunakan dalam pembelajaran. Jika dikaitkan dengan nilai sebagian siswa masih tergolong rendah yaitu 6,5. Penggunaan media pembelajaran yang kurang tepat dapat membosankan siswa dalam belajar, sehingga kreativitas siswa kurang dapat di eksplor. Beberapa kendala yang dialami siswa dalam proses pembelajaran di atas berdampak pada kualitas proses dan hasil pembelajaran yang kurang maksimal sehingga keterampilan menulis teks eksplanasi siswa tidak maksimal.

Masalah-masalah yang timbul di kelas tersebut, jika tidak segera diatasi menyebabkan siswa semakin kesulitan mengemukakan idenya, terutama berkaitan dengan menulis teks ekslpanasi. Ini tentu saja membuat pembelajaran bahasa Indonesia menjadi terhambat. Pada akhirnya tujuan pembelajaran bahasa Indonesia sebagai bagian dari Kurikulum 2013 yang menekankan pentingnya keseimbangan kompetensi sikap, pengetahuan dan keterampilan, kemampuan berbahasa yang dituntut tersebut dibentuk melalui pembelajaran berkelanjutan menjadi tidak tercapai. Kompetensi keterampilan menyajikan suatu teks tulis dan lisan baik terencana maupun spontan, dan bermuara pada pembentukan sikap kesantunan berbahasa dan penghargaan terhadap Bahasa Indonesia sebagai warisan budaya bangsa menjadi jauh dari harapan. Oleh karena itu sebuah media atau alat bantu dapat dijadikan sebagai alat untuk membantu dan membenahi serta menggali potensi siswa dalam keterampilan berbahasa. Penelitian ini menggunakan media pembelajaran yang mudah ditemukan dan dipergunakan berupa media gambar berseri.

Gambar berseri adalah rangkaian gambar yang menceritakan suatu peristiwa. Setiap gambar menceritakan bagian dari cerita tersebut. Gambar tersebut dapat disusun secara urut sehingga membentuk sebuah cerita yang runtut. Langkah pertama mengurutkan gambar seri adalah menemukan judul cerita dalam berseri tersebut. Setelah menemukan judul dalam gambar berseri tersebut, selanjutnya adalah menentukan peristiwa pertama yang mungkin terjadi dalam gambar tersebut Selanjutnya, menentukan peristiwa yang lain yang disusun secara logis sehingga membentuk cerita yang runtut. Menurut Brown dkk (dalam Sudjana, 2010:12) ilustrasi gambar merupakan perangkat pengajaran yang dapat menarik minat belajar siswa secara efektif. Dengan menerapkan gambar berseri ke dalam kegiatan menulis teks eskplanasi, minat belajar siswa akan tertarik pada pesan gambar yang ditampilkan. Dan hal ini dapat membantu siswa untuk lebih mudah memahami materi yangdiberikan. Tujuan diadakan penelitian ini yaitu untuk meningkatkan keterampilan siswa dalam menulis teks eksplanasi dengan menggunakan media gambar berseri.

Keterampilan berbahasa yang dapat dihubungkan dengan media gambar diam adalah menulis dan berbicara. Menulis selain sebagai kegiatan kreativitas juga merupakan kegiatan produktif dan ekspresif. Keterampilan menulis juga digunakan untuk mencatat, merekam, meyakinkan, menginformasikan, dan mempengaruhi pembaca. Hal ini dapat dicapai dengan baik jika penulis yaitu siswa mampu menyusun dan merangkai jalan pikiran serta mengemukakannya secara tertulis dengan jelas, lancar, dan komunikatif (Syarkawi, 2008 : 2). Menulis pada prinsipnya adalah bercerita tentang sesuatu yang ada di angan-angan pencerita dan dapat menuangkan dalam bentuk tulisan. Namun, menuangkan buah pikiran secara teratur dan terorganisasi ke dalam tulisan tidak mudah.

Dalam kegiatan menulis, penulis juga harus bisa memanfaatkan bahasa dan kosakata yang diperolehnya. Penulis juga harus memahirkan kegiatan menulis tersebut dalam latihan-latihan tertentu sehingga dapat benarbenar menguasai keterampilan menulis tersebut. Menulis selain dapat menjadi ajang sebuah kreativitas juga dapat dijadikan sebagai penyampai gagasan tentang suatu hal. Salah satu cara untuk meningkatkan proses belajar mengajar menulis adalah dengan mengubah media atau pola ajar yang digunakan oleh guru. 
Berdasarkan pengamatan tersebut, peneliti tertarik untuk meningkatkan kemampuan menulis teks eksplanasi siswa kelas VII 8 SMPN 1 Banuhampu menggunakan media gambar berseri. Kata "Media" secara harpiah adalah "perantara atau pengantar". Penger-tian media sebagai sumber belajar adalah "Manusia, benda, ataupun peristiwa yang memungkinkan siswa memperoleh pengetahuan dan keterampilan" (Djamarah dan Zein, 1996: 136). Sedangkan menurut Gagne (Arief S. Sadiman, 2007: 6) media adalah berbagai jenis komponen dalam lingkungan siswa yang dapat merangsangnya untuk belajar. Jadi media adalah alat bantu apa saja yang dapat dijadikan sebagai penyalur pesan guna merangsang pikiran, perasaan, dan kemauan siswa untuk belajar.

Judul penelitian ini "Peningkatkan Kemampuan Menulis Teks Eksplanasi dengan Menggunakan Media Gambar Berseri pada Siswa Kelas VII 8 SMPN I Banuhampu". Rumusan masalah dalam penelitian ini adalah bagaimanakah penggunaan gambar berseri dapat meningkatkan kemampuan menulis teks eksplanasi siswa kelas VII 8 SMPN 1 Banuhampu? Tujuan penelitian ini untuk meningkatkan kemampuan menulis teks eksplanasi dengan menggunakan media gambar berseri di kelas VII 8 SMPN 1 Banuhampu.

\section{METODE}

Penelitian yang dilakukan yaitu penelitian tindakan kelas (TTK). Penelitian tindakan kelas ini dilaksanakan di SMP Negeri 1 Banuhampu Kabupaten Agam. Subjek penelitian adalah siswa kelas VII 8 SMP Negeri 1 Banuhampu yang berjumlah 31 orang. Penelitian Tindakan Kelas (PTK) ini di rencanakan dalam dua siklus yang masing-masing siklus terdiri dari tahap perencanaan, pengamatan, pelaksanaan tindakan, dan refleksi. Langkahlangkah yang ditempuh dalam masing-masing siklus, sebagai berikut.

\section{Siklus I}

Perencanaan untuk mempersiapkan dan merancang komponen-komponen yang berkaitan dengan pelaksanaan penelitian tindakan kelas. Komponen-komponen itu terdiri dari Rencana Pelaksanaan Pembelajaran, yang dilengkapi dengan penugasan dan format penilaian pembelajaran menulis teks eksplanasi. Pelaksanaan, Pada tahap ini guru mencoba menerapkan kegiatan pembelajaran menulis teks eksplanasi dengan mengikuti prosedur pembelajaran yang telah tertuang dalam Rencana Pelaksanaan Pembelajaran. Siswa ditugasi untuk mengamati media gambar berseri yang telah di pajang guru di papan tulis kemudian diminta untuk mendata katakata yang berhubungan dengan objek yang diamati. Setelah itu siswa ditugasi untuk merangkai kata-kata yang telah di datanya menjadi teks eksplanasi. Untuk mengukur keberhasilan siswa dalam pembelajaran menulis teks eskplanasi dilakukan penilaian dengan menggunakan format penilaian yang telah di siapkan berdasarkan indikator yang telah ditetapkan.

Analisis dan Refleksi, pada tahap ini, melakukan analisis terhadap hasil pembelajaran menulis teks eksplanasi dengan menggunakan media gambar berseri secara tertulis. Hasil penelitian diperoleh dengan menggunakan tabulasi yang kemudian dipresentasekan. Berdasarkan hasil analisis, dilakukan refleksi untuk merencanakan tindakan berikutnya yang akan dilakukan pada siklus kedua.

\section{Siklus II}

Siklus kedua tetap mengikuti siklus penelitian tindakan kelas yakni perencanaan, pelaksanaan dan refleksi dengan mempertimbangkan temuan pada siklus I. Perencanaan dibuat dalam bentuk RPP berdasarkan kelemahan yang ditemukan pada siklus I. RPP ini juga di lengkapi dengan format penilaian pembelajaran menulis teks eksplanasi. Pelaksanaan, Pada tahap ini guru mencoba menerapkan kegiatan pembelajaran menulis teks eksplanasi dengan mengikuti prosedur pembelajaran yang telah tertuang dalam RPP. Pada siklus II ini sebelum menulis teks eksplanasi siswa ditugaskan mengidentifikasi unsur kebahasaan yang dominan dalam teks eksplanasi. Setelah itu siswa ditugaskan kembali mengamati media gambar berseri yang telah dipajang guru di papan tulis. Kemudian siswa diminta untuk mendata fakta-fakta yang berhubungan dengan objek yang diamati. Siswa lain menanggapi fakta-fakta yang telah ditampilkan oleh temannya. Setelah mendapat pertimbangan dan saran dari temannya, siswa merangkai pilihan data dan fakta tersebut kedalam sebuah kalimat dalam teks eksplanasi dan kalimat-kalimat tersebut disusun secara berurutan menjadi teks eksplanasi yang utuh. Untuk mengukur keberhasilan siswa dalam pembelajaran menulis teks eksplanasi, peneliti melakukan penilaian dengan menggunakan format penilaian yang telah disiapkan berdasarkan indikator yang telah ditetapkan. 
Analisis dan Refleksi, pada tahap ini peneliti melakukan analisis terhadap hasil penilaian teks eksplanasi siswa. Nilai itu dianalisis dengan menggunakan tabulasi yang kemudian dipresentasikan. Selain itu peneliti juga menganalisis hasil obeservasi yang dilakukan terhadap guru dan siswa. Beberapa catatan atau hasil temuan lapangan juga akan ditampilkan dalam bagian ini.

\section{HASIL DAN PEMBAHASAN}

Hasil Penelitian

Siklus I

\section{Perencanaan}

Pada siklus 1 langkah-langkah yang dilakukan adalah berkaitan dengan pemodelan teks eksplanasi. Pada tahap ini waktu yang disediakan adalah 2x pertemuan ( 6 x 40 menit). Rincian kegiatan pada tahap ini adalah (1) menyusun dan mempersiapkan instrumen pembelajaran berupa RPP dengan naskah teks eksplanasi yang terdapat pada buku pegangan siswa. Pemodelan dimulai dengan memperkenalkan tema peristiwa melalui gambar yang dicermati siswa dari buku pengangannya. (2) Menetapkan jadwal pelaksanaan penelitian. (3) Menentukan 6 kelompok, satu kelompok terdiri atas 5-6 siswa. (4) Mempersiapkan format penilaian, lembar observasi, daftar nama, dan catatan lapangan.

\section{Pelaksanaan Tindakan}

Pelaksanaan tindakan dilakukan dengan langkah-langkah berikut ini. (1) Guru menjelaskan rencana kegiatan saat itu dan memotivasi siswa menyebutkan dan menjelaskan peristiwa-peritiwa yang ada atau ditemui di sekitarnya. (2) Siswa dipandu mengomentari peristiwa yang berkaitan dengan gambar berseri yang diperlihatkan. (3) Siswa mengindentifikasi peristiwa yang terdapat pada gambar-gambar yang diamatinya. (4) Dengan bertanya jawab siswa dipandu mengemukakan pendapatnya tentang sebab dan akibat terjadinya peristiwa dalam gambar. (5) Guru membentuk 6 kelompok, satu kelompok terdiri dari 5 -6 siswa. (7) Menyusun peristiwa yang telah diidentifikasi sesuai denga struktur teks eksplanasi. (8) Guru menugasi masing-masing membaca teks eskplanasi yang telah ada dalam buku pegangannya. (9) Guru mengamati proses kegiatan pembelajaran. Guru sebagai fasilitator dan motivator dalam kegiatan diskusi di kelompok. Siswa dalam kelompoknya menjawab beberapa pertanyaan yang berkaitan dengan teks. Kemudian memasukkan bagian-bagian teks sesuai dengan struktur teks eksplanasi. Masing-masing kelompok menulis teks eksplanasi berdasartkan teks yang sudah ada dengan kata-kata sendiri.(10) Masing-masing kelompok mempresentasikan hasil diskusinya ke depan kelas. (11) Kelompok lain menanggapi hasil diskusi kelompok dan mencatat temua-temuan yang berkaitan dengan kebahasaan. (12) Siswa menuliskan kembali secara mandiri teks eksplanasi. (13) Siswa dan guru mengadakan penguatan yaitu membetulkan struktur teks eksplanasi dan hal-hal yang kurang tepat.

\section{Observasi}

Berdasarkan data pengamatan (observasi) setelah diberikan tindakan pada siklus I, peneliti dapat mengungkapkan perubahan-perubahan yang terjadi pada siswa, diantaranya :

a. Siswa sudah memahami struktur teks eksplanasi tapi masih mengalami kesulitan saat ditugaskan menuliskan kembali teks yang sudah ada dengan kata-kata sendiri.

b. Dengan bekerjasama dalam kelompok, siswa bisa mengidentifikasi peristiwa-peristiwa yang terdapat dalam teks eksplanasi yang telah tersedia.

c. Pada waktu tampil, baik secara individu maupun dalam kelompok, ternyata masih terlihat kekurangan pada masing-masing teks yang dihasilkan.

d. Sebagian besar hasil tulisan siswa hanya menyalin kembali teks yang sudah ada ke dalam struktur teks eksplanasi.

Ternyata berlatih menulis teks eksplanasi dengan menggunakan gambar berseri dalam kelompok cukup membuahkan hasil. Masing-masing siswa dapat memahami struktur teks dan mekanisme penulisan teks eksplanasi. Dari 31 orang siswa di kelas VII 8 SMPN 1 Banuhampu terdapat 19 siswa kurang mampu menulis teks eksplanasi, 12 siswa cukup mampu, dan belum ada siswa yang mampu menulis teks eksplanasi sesuai dengan kaidah penulisan yang benar. 
Hasil observasi menunjukkan bahwa siswa masih terfokus hanya pada memahami struktur dan mekanik pembangun teks. Namun pada saat menuangkan kembali idenya ke dalam tulisan dengan kata-kata sendiri, siswa masih mengalami kesulitan, terutama berkaitan dengan kosa kata. Kalimat-kalimat yang dibuat belum merupakan kalimat sendiri tetapi masih kalimat-kalimat dari teks yang sudah ada. Sedangkan pada masalah isi masih belum tergambar dengan baik. Demikian pula pada masalah koherensi kalimat. Hasil yang diperoleh pada tahap awal menulis teks eksplanasi dapat dilihat pada tabel berikut:

Tabel 1. Kemampuan Menulis Teks Eksplanasi Menggunakan Media Gambar Berseri Pada Siklus I

\begin{tabular}{|c|c|c|c|c|c|c|c|c|c|c|}
\hline No & Nama & Isi & $\begin{array}{c}\text { Struk } \\
\text { tur }\end{array}$ & $\begin{array}{l}\text { Kosa } \\
\text { Kata } \\
\end{array}$ & $\begin{array}{l}\text { Kali } \\
\text { mat }\end{array}$ & $\begin{array}{c}\text { Meka } \\
\text { nik }\end{array}$ & $\begin{array}{l}\text { Total } \\
\text { Nilai }\end{array}$ & $\begin{array}{l}\text { (1- } \\
4)\end{array}$ & $\begin{array}{l}\text { Kon } \\
\text { versi }\end{array}$ & Predi kat \\
\hline & Skor Maksimal & 30 & 20 & 20 & 20 & 10 & & & & \\
\hline 1 & Abdullah Rahmad & 20 & 18 & 15 & 15 & 8 & 76 & 3,04 & $\mathrm{~B}+$ & $\mathrm{B}$ \\
\hline 2 & Agus Kurniawan & 17 & 14 & 12 & 12 & 6 & 61 & 2,44 & B- & $\mathrm{C}$ \\
\hline 3 & Annisa Salsabila & 17 & 14 & 12 & 12 & 7 & 62 & 2,48 & B- & $\mathrm{C}$ \\
\hline 4 & Arfatil Huda & 16 & 14 & 10 & 14 & 6 & 60 & 2,4 & B- & $\mathrm{C}$ \\
\hline 5 & Ayu Wahyuni & 17 & 14 & 12 & 12 & 6 & 61 & 2,44 & B- & $\mathrm{C}$ \\
\hline 6 & Deanita & 20 & 14 & 10 & 14 & 7 & 65 & 2,6 & B- & B \\
\hline 7 & Deby Sintia & 17 & 14 & 12 & 12 & 7 & 62 & 2,48 & B- & $\mathrm{C}$ \\
\hline 8 & Delfi Marlina & 20 & 14 & 14 & 14 & 7 & 69 & 2,76 & B & B \\
\hline 9 & Erik Hidayat & 17 & 14 & 12 & 14 & 5 & 62 & 2,48 & B- & $\mathrm{C}$ \\
\hline 10 & Fadhila Rahmi & 20 & 14 & 10 & 12 & 7 & 63 & 2,52 & B- & $\mathrm{C}$ \\
\hline 11 & Fedri Exel & 21 & 16 & 12 & 15 & 8 & 72 & 2,88 & $\mathrm{~B}$ & B \\
\hline 12 & Firda Aulia Rahmi & 17 & 16 & 12 & 14 & 8 & 67 & 2,68 & B & B \\
\hline 13 & Huswatun Hasanah & 16 & 14 & 10 & 15 & 8 & 63 & 2,52 & B- & $\mathrm{C}$ \\
\hline 14 & Lusy Ariska R. & 17 & 14 & 12 & 14 & 6 & 63 & 2,52 & B- & $\mathrm{C}$ \\
\hline 15 & Muhammad Arifin & 20 & 14 & 8 & 14 & 7 & 63 & 2,52 & B- & $\mathrm{C}$ \\
\hline 16 & Muhammad Hengki & 18 & 14 & 10 & 10 & 7 & 59 & 2,36 & B- & $\mathrm{C}$ \\
\hline 17 & Nadia Stefani & 17 & 14 & 12 & 14 & 8 & 65 & 2,6 & B- & B \\
\hline 18 & Natasya Aulia Putri & 17 & 14 & 12 & 10 & 7 & 60 & 2,4 & B- & $\mathrm{C}$ \\
\hline 19 & Noval Adi Putra & 16 & 14 & 10 & 15 & 7 & 62 & 2,48 & B- & $\mathrm{C}$ \\
\hline 20 & Nurmahmud Ismail & 17 & 14 & 10 & 14 & 5 & 60 & 2,4 & B- & $\mathrm{C}$ \\
\hline 21 & Nurul Fadhila & 17 & 14 & 12 & 14 & 8 & 65 & 2,6 & B- & $\mathrm{B}$ \\
\hline 21 & Ramadhani H. & 16 & 14 & 10 & 15 & 6 & 61 & 2,44 & B- & $\mathrm{C}$ \\
\hline 23 & Ratu Hazira & 17 & 14 & 14 & 14 & 7 & 66 & 2,64 & B- & B \\
\hline 24 & Rizka Rahmadini & 17 & 14 & 14 & 10 & 7 & 62 & 2,48 & B- & $\mathrm{C}$ \\
\hline 25 & Sri Rahayu Andani & 20 & 14 & 12 & 14 & 7 & 67 & 2,68 & $\mathrm{~B}$ & $\mathrm{~B}$ \\
\hline 26 & Sri Rahmayanti & 22 & 12 & 16 & 14 & 8 & 72 & 2,88 & $\mathrm{~B}$ & $\mathrm{~B}$ \\
\hline 27 & Taufik Hidayat & 16 & 14 & 12 & 12 & 6 & 60 & 2,4 & B- & $\mathrm{C}$ \\
\hline 28 & Tomi Ofrananda & 16 & 14 & 12 & 12 & 6 & 60 & 2,4 & B- & $\mathrm{C}$ \\
\hline 29 & Vandy Dwi Putra & 20 & 14 & 12 & 14 & 8 & 68 & 2,72 & B & B \\
\hline 30 & Walyyah Nabila & 17 & 14 & 14 & 10 & 8 & 63 & 2,52 & B- & $\mathrm{C}$ \\
\hline \multirow[t]{2}{*}{31} & Yulia Permata Sari & 17 & 15 & 14 & 14 & 7 & 67 & 2,68 & B & B \\
\hline & Jumlah Skor & 582 & 461 & 389 & 429 & 225 & 1986 & & & \\
\hline
\end{tabular}




$\begin{array}{crrrrrr}\text { Skor Maksimal } & 930 & 620 & 620 & 620 & 310 & 3100 \\ \% \text { Skor Tercapai } & 63 \% & 74 \% & 63 \% & 69 \% & 73 \% & \end{array}$

Tabel di atas menunjukkan bahwa (1) Dari 31 siswa ternyata cukup mampu menulis teks eksplanasi dengan menggunakan media gambar berseri ada 12 orang atau $40 \%$. (2) Siswa yang kurang mampu membacakan teks eksplanasi dengan media gambar berseri ada 19 orang atau 63,3\%. (3) Data tersebut menunjukkan bahwa siswa masih kurang berhasil menulis teks eksplanasi. Artinya Siswa masih belum berhasil menuangkan idenya dalam bentuk teks eksplanasi. Dari data ini ternyata masih belum memenuhi harapan peneliti untuk mencapai target yang diinginkan. Hal ini bisa dilihat pada grafik 1 berikut ini.

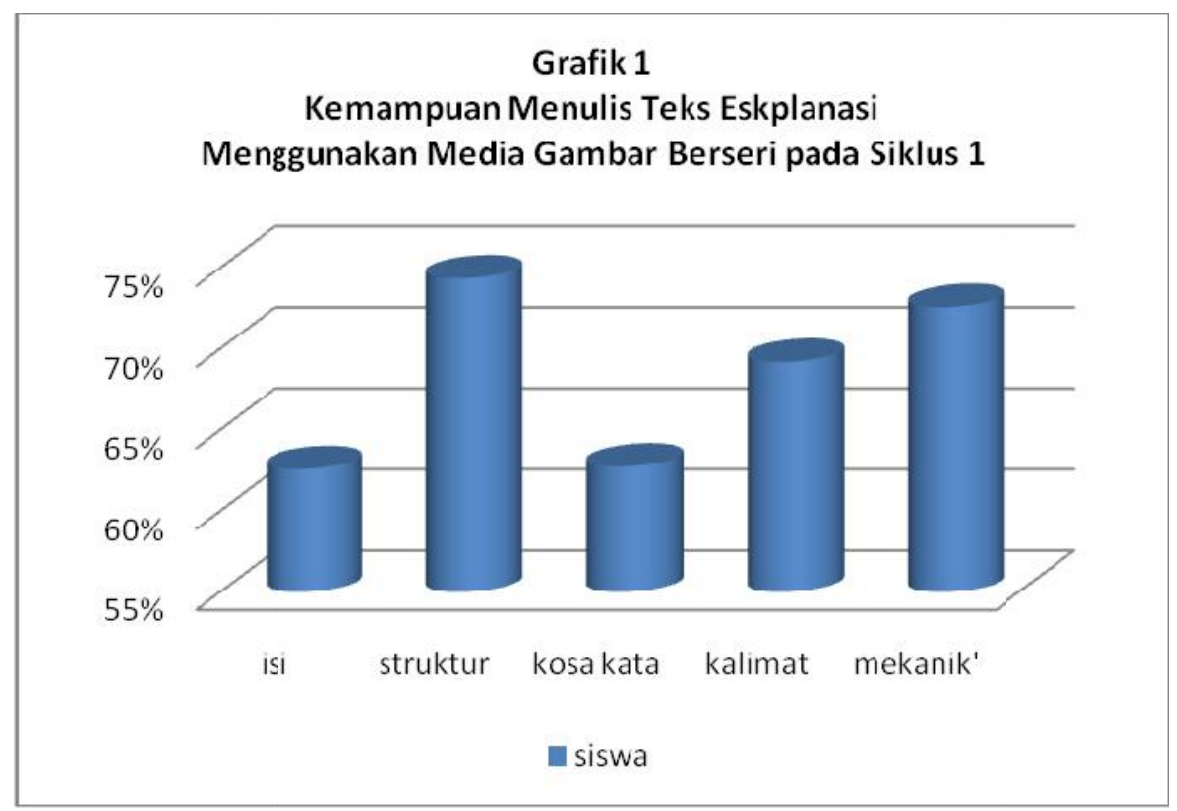

Dari 5 komponen yang dinilai ternyata masih ada kendala yang menyebabkan kurang berhasilnya pembelajaran menulis teks eksplanasi yaitu memahami isi teks eksplanasi dan mekanisme penulisannya. Walaupun secara umum, siswa memahami struktur dan kalimat-kalimat yang harus dituliskan. Dari data di atas menunjukkan bahwa antara isi dan mekanisme penulisan teks eksplanasi perlu mendapatkan perhatian karena belum memenuhi syarat karena kurang dari $65 \%$.

\section{Refleksi}

Dari hasil pengamatan secara keseluruhan dapat disimpulkan bahwa kemampuan menulis teks eksplanasi siswa kelas VII 8 di SMP Negeri 1 Banuhampu masih belum maksimal pada siklus I karena belum memenuhi target peneliti. Beberapa kendala yang dihadapi pada siklus I antara lain:

a. Dari 6 kelompok yang ada ternyata siswa yang termasuk pandai belum tersebar, seharusnya siswa tersebut disebar ke kelompok-kelompok yang lain sehingga suasana kelas lebih hidup dan kerja setiap kelompok bisa berhasil. Siswa-siswa yang pandai bisa memacu semangat dan motivasi kelompoknya.

b. Siswa kurang tertarik mengeluarkan idenya karena gambar yang ada sudah didampingi teks yang sudah ada dalam bukunya dan peristiwanya bukan peristiwa yang baru.

c. Keaktifan siswa untuk memberi arahan kepada temannya hanya tampak pada 2 kelompok saja.

d. Pada saat siswa menulis, masing-masing kelompok hanya terfokus pada struktur teks, tanpa mengamati lebih jauh tentang isi dan kosa kata dan kalimat-kalimat untuk penulisan teks eskplanasi.

e. Pada saat mempresentasikan hasil kerja, kurang terlihat bahwa teks yang dihasilkan sudah menggunkan katakata sendiri, sebagian besar masih menyalin teks yang sudah ada. 
Dengan memperhatikan kendala yang ditemui pada siklus I maka peneliti melanjutkan ke pelaksanaan siklus II agar kemampuan menulis teks eksplanasi melalui media gambar berseri meningkat. Hanya saja gambar yang dipilih adalah gambar dengan peristiwa terbaru dan mereka alami. Selain itu, gambar yang ditampilkan tidak didampingi teks seperti pada siklus 1. Langkah-langkah yang dilakukan peneliti untuk mengatasi permasalahan pada siklus I antara lain adalah:

1. Guru menjelaskan rencana kegiatan pada saat itu yaitu melatih menulis teks eksplanasi dengan aturan yang benar.

2. Guru memberi wawasan tentang berbahasa Indonesia yang baik dan benar.

3. Guru membagi 6 kelompok yang terdiri dari 5-6 anggota. Siswa yang pandai dan aktif disebar ke 6 kelompok dengan tujuan agar suasana kelas lebih hidup dan kerja kelompok optimal.

4. Guru memperlihatkan gambar berseri tentang peristiwa kabut asap yang disebabkan kebakaran hutan.

5. Siswa memperhatikan gambar berseri tersebut dengan cermat

6. Bersama kelompoknya siswa mengidentifikasi peristiwa-peristiwa yang terdapat dalam gambar.

7. Siswa membuat kalimat sebab akibat dari peristiwa yang terdapat dalam gambar dalam kelompoknya.

8. Siswa mengelompokkan kalimat-kalimat tersebut berdasarkan struktur teks eksplanasi

9. Masing-masing kelompok mempresentasikan hasil diskusinya dan ditanggapi oleh kelompok lain.

10. Guru mempersiapkan instrumen yang diperlukan.

11. Siswa ditugaskan menulis teks eksplanasi secara mandiri

\section{Siklus II}

\section{Perencanaan}

Hasil refleksi pada siklus I diketahui bahwa masih terdapat indikator yang memerlukan perbaikan. Perbaikan yang dilakukan dalam pelaksanaan pembelajaran menulis teks eksplanasi melalui media gambar berseri yaitu :

1. Guru menyusun dan mempersiapkan instrumen pembelajaran yaitu rencana pembelajaran dengan menggunakan media gambar berseri tentang peristiwa kabut asap.

2. Tahap pendahuluan guru menambah wawasan tentang cara menulis teks eksplanasi melalui revisi dari contohcontoh yang ditemukan dari hasil temuan pada siklus I.

3. Guru menginformasikan bahwa teks eksplanasi harus sesuai dengan tema gambar dan berbeda dengan siklus I.

\section{Pelaksanaan Tindakan}

\section{Tindakan yang dilakukan pada siklus}

1. Guru menjelaskan rencana kegiatan saat itu dan memotivasi siswa untuk menghasilkan tulkisan teks eksplanasi yang lebih baik lagi.

2. Siswa mengamati gambar berseri yang ditampilkan di papan tulis.

3. Siswa dipandu guru mengomentari peristiwa yang terdapat berkaitan dengan gambar berseri yang ditampilkan termasuk yang berkaitan dengan susunan gambar berseri.

4. Siswa mengindentifikasi peristiwa-peritiwa yang terdapat dalam gambar berseri.

5. Dengan bertanya jawab siswa dipandu mengemukakan pendapatnya tentang sebab dan akibat terjadinya peristriwa dalam gambar berseri.

6. Guru membentuk 6 kelompok, satu kelompok terdiri dari 5 -6 siswa.

7. Guru menugasi masing-masing kelompok mengidentifaksi kata-kata yang berkaitan dengan peristiwa dalam gambar berseri kemudian membuat kalimat sebab akibat dengan kata-kata tersebut.

8. Peneliti mengamati proses kegiatan belajar mengajar. Peneliti sebagai fasilitator dan motivator pada saat diperlukan kelompok diskusi.

9. Masing-masing kelompok mempresentasikan kerjanya ke depan kelas.

10. Kelompok lain menanggapi dan mendiskusikan kalimat-kalimat yang tidak cocok dengan peristiwa dalam gambar berseri termasuk unsur kebahasaannya.

11. Guru memberi penegasan terhadap hasil diskusi.

12. Masing-masing siswa ditugaskan mengelompokkan kalimat-kalimat tersebut berdasarkan struktur teks eksplanasi dan langsung menjadikannya kerangka karangan teks eksplanasi 
13. Masing-masing siswa mengembangkang kerangka tersebut menjadi teks eksplanasi yang utuh bertema kabut asap.

14. Siswa mempresentasikan hasil karyanya di depan kelas.

15. Siswa dan guru menyimpulkan kegiatan menulis teks eksplanasi tersebut dan memberikan penguatan serta memperbaiki struktur teks eksplanasi dan hal-hal masih kurang tepat.

\section{Observasi}

Dalam tahap ini peneliti mengajukan hasil pengamatan dan hasil penilaian yang diperoleh para siswa setelah mengikuti proses pelajaran membacakan teks eksplanasi dengan media gambar berseri siswa kelas VII 8 di SMP Negeri 1 Banuhampu. data hasil pengamatan dapat peneliti sajikan sebagai berikut:

Tabel 2. Kemampuan Menulis Teks Eksplanasi Menggunakan Media Gambar Berseri Pada Siklus II

\begin{tabular}{|c|c|c|c|c|c|c|c|c|c|c|}
\hline No & Nama & Isi & $\begin{array}{c}\text { Struk } \\
\text { tur }\end{array}$ & $\begin{array}{l}\text { Kosa } \\
\text { Kata }\end{array}$ & $\begin{array}{l}\text { Kali } \\
\text { mat }\end{array}$ & $\begin{array}{c}\text { Meka } \\
\text { nik }\end{array}$ & $\begin{array}{l}\text { Total } \\
\text { Nilai }\end{array}$ & $(1-4)$ & $\begin{array}{c}\text { Kon } \\
\text { versi }\end{array}$ & $\begin{array}{c}\text { Predik } \\
\text { at }\end{array}$ \\
\hline & Skor Maksimal & 30 & 20 & 20 & 20 & 10 & & & & \\
\hline 1 & Abdullah Rahmad & 28 & 20 & 18 & 18 & 10 & 94 & 3,76 & A & SB \\
\hline 2 & Agus Kurniawan & 20 & 14 & 14 & 14 & 5 & 67 & 2,68 & $\mathrm{~B}$ & B \\
\hline 3 & Annisa Salsabila & 28 & 19 & 18 & 18 & 10 & 93 & 3,72 & A & SB \\
\hline 4 & Arfatil Huda & 28 & 20 & 18 & 18 & 10 & 94 & 3,76 & A & SB \\
\hline 5 & Ayu Wahyuni & 24 & 14 & 14 & 14 & 7 & 73 & 2,92 & B & $\mathrm{B}$ \\
\hline 6 & Deanita & 25 & 14 & 12 & 14 & 7 & 72 & 2,88 & $\mathrm{~B}$ & $\mathrm{~B}$ \\
\hline 7 & Deby Sintia & 28 & 20 & 18 & 18 & 10 & 94 & 3,76 & A & SB \\
\hline 8 & Delfi Marlina & 28 & 20 & 18 & 18 & 7 & 91 & 3,64 & A- & SB \\
\hline 9 & Erik Hidayat & 17 & 14 & 14 & 14 & 7 & 66 & 2,64 & B- & $\mathrm{B}$ \\
\hline 10 & Fadhila Rahmi & 28 & 18 & 18 & 18 & 10 & 92 & 3,68 & A & SB \\
\hline 11 & Fedri Exel & 28 & 20 & 18 & 18 & 10 & 94 & 3,76 & A & SB \\
\hline 12 & Firda Aulia Rahmi & 17 & 16 & 16 & 14 & 8 & 71 & 2,84 & $\mathrm{~B}$ & B \\
\hline 13 & Huswatun Hasanah & 28 & 20 & 18 & 18 & 6 & 90 & 3,6 & A- & SB \\
\hline 14 & Lusy Ariska Ramadhan & 28 & 18 & 18 & 18 & 10 & 92 & 3,68 & A & SB \\
\hline 15 & Muhammad Arifin & 25 & 14 & 12 & 14 & 7 & 72 & 2,88 & B & B \\
\hline 16 & Muhammad Hengki & 25 & 14 & 12 & 14 & 7 & 72 & 2,88 & B & B \\
\hline 17 & Nadia Stefani & 28 & 20 & 18 & 18 & 10 & 94 & 3,76 & A & SB \\
\hline 18 & Natasya Aulia Putri & 25 & 14 & 14 & 14 & 7 & 74 & 2,96 & B & $\mathrm{B}$ \\
\hline 19 & Noval Adi Putra & 25 & 14 & 12 & 15 & 7 & 73 & 2,92 & B & $\mathrm{B}$ \\
\hline 20 & Nurmahmud Ismail & 24 & 14 & 14 & 14 & 7 & 73 & 2,92 & B & $\mathrm{B}$ \\
\hline 21 & Nurul Fadhila & 28 & 20 & 18 & 18 & 10 & 94 & 3,76 & A & SB \\
\hline 22 & Ramadhani Hidayat & 20 & 14 & 12 & 15 & 6 & 67 & 2,68 & B & $\mathrm{B}$ \\
\hline 23 & Ratu Hazira & 28 & 18 & 18 & 18 & 10 & 92 & 3,68 & A & SB \\
\hline 24 & Rizka Rahmadini & 28 & 20 & 18 & 18 & 10 & 94 & 3,76 & A & SB \\
\hline 25 & Sri Rahayu Andani & 25 & 14 & 12 & 14 & 7 & 72 & 2,88 & $\mathrm{~B}$ & $\mathrm{~B}$ \\
\hline 26 & Sri Rahmayanti & 28 & 18 & 18 & 18 & 7 & 89 & 3,56 & A- & $\mathrm{B}$ \\
\hline 27 & Taufik Hidayat & 17 & 14 & 12 & 14 & 6 & 63 & 2,52 & B- & $\mathrm{C}$ \\
\hline 28 & Tomi Ofrananda & 15 & 14 & 12 & 15 & 7 & 63 & 2,52 & B- & $\mathrm{C}$ \\
\hline 29 & Vandy Dwi Putra & 28 & 20 & 18 & 18 & 10 & 94 & 3,76 & A & SB \\
\hline
\end{tabular}




\begin{tabular}{rlccccccccc}
\hline $\mathbf{3 0}$ & Walyyah Nabila & 27 & 20 & 18 & 18 & 10 & 93 & 3,72 & A & SB \\
$\mathbf{3 1}$ & Yulia Permata Sari & 28 & 20 & 18 & 18 & 10 & 94 & 3,76 & A & SB \\
& Jumlah Skor & $\mathbf{8 0 9}$ & $\mathbf{5 4 9}$ & $\mathbf{5 0 8}$ & $\mathbf{5 2 5}$ & $\mathbf{2 6 5}$ & $\mathbf{2 5 5 6}$ & & & \\
& Skor Maksimal & $\mathbf{9 3 0}$ & $\mathbf{6 2 0}$ & $\mathbf{6 2 0}$ & $\mathbf{6 2 0}$ & $\mathbf{3 1 0}$ & $\mathbf{3 1 0 0}$ & & & \\
& \% Skor tercapai & $\mathbf{8 7 \%}$ & $\mathbf{8 9 \%}$ & $\mathbf{8 2 \%}$ & $\mathbf{8 5 \%}$ & $\mathbf{8 5 \%}$ & & & & \\
\hline
\end{tabular}

Dari hasil tabel siklus II dapat disimpulkan sebagai berikut :

1. Dari 31 siswa ternyata sudah sangat baik hasil menulsi teks eksplanasinya sebanyak 16 orang atau $51,61 \%$

2. Siswa yang teks eksplanasinya sudah baik sebanyak 12 orang atau $38,71 \%$

3. Siswa yang masih kurang bagus hasil penulisan teks ekplanasinya 2 orang atu $6,45 \%$

Hal ini menujukkan bahwa kemampuan menulis teks eksplanasi dengan bantuan media gambar berseri siswa kelas VII 8 SMPN Banuhampu meningkat. Dari data tersebut juga didapati bahwa hasil menulis siswa sudah berimbang antara komponen isi, struktur, kosa kata, kalimat dan mekanisme teks eskplanasi. Hal ini bisa dilihat pada grafik II (dua) berikut ini.

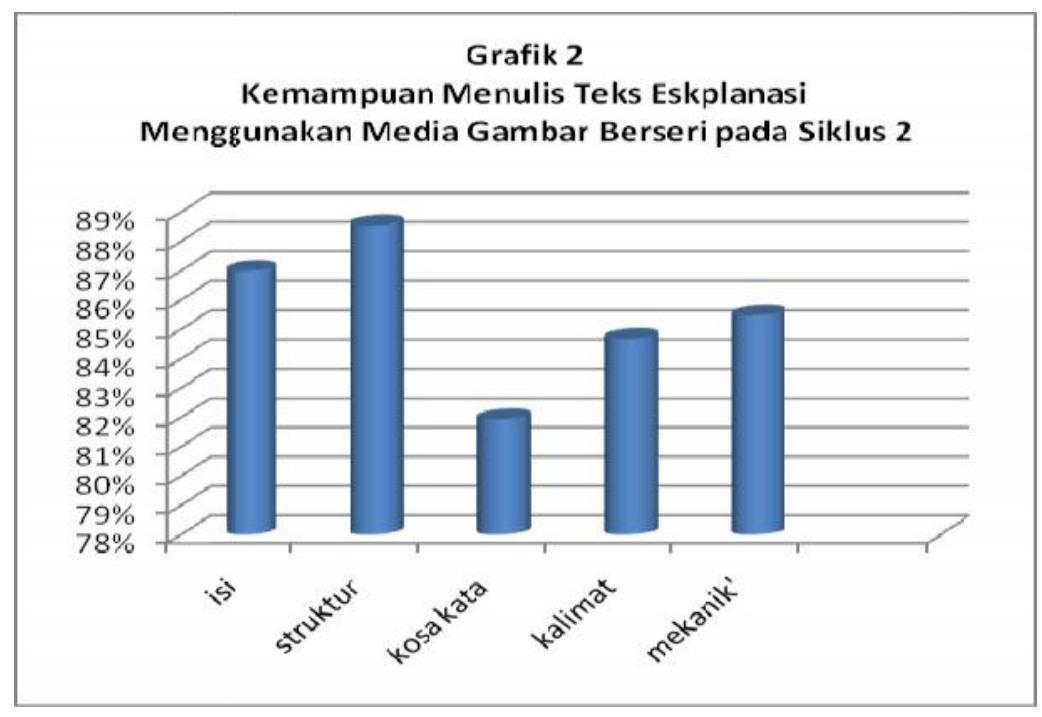

Dari data grafik 2 siklus II ternyata hasil yang diperoleh sudah melebihi target peneliti dan sudah dikatagorikan berhasil. Dengan demikian dapat ditarik kesimpulan bahwa melalui media gambar berseri kemampuan menulis teks eksplanasi siswa kelas VII 8 SMP Negeri 1 Banuhampu meningkat.

\section{Pembahasan}

Pembelajaran Bahasa Indonesia yang diamanatkan dalam kurikulum 2013 adalah pembelajaran bahasa Indonesia berbasis teks. Pembelajaran bahasa Indonesia berbasis teks, menurut Dr. Tri Wiratno, M.A. (2013) dilaksanakan dengan menerapkan prinsip bahwa (1) bahasa hendaknya dipandang sebagai teks, bukan sematamata kumpulan kata-kata atau kaidah-kaidah kebahasaan, (2) penggunaan bahasa merupakan proses pemilihan bentuk-bentuk kebahasaan untuk mengungkapkan makna, (3) bahasa bersifat fungsional, yaitu penggunaan bahasa yang tidak pernah dapat dilepaskan dari konteks karena bentuk bahasa yang digunakan itu mencerminkan ide, sikap, nilai, dan ideologi penggunanya, dan (4) bahasa merupakan sarana pembentukan kemampuan berpikir manusia, dan cara berpikir seperti itu direalisasikan melalui struktur teks.

Teks adalah satuan bahasa yang mengandung makna, pikiran, dan gagasan yang lengkap secara dituju oleh pesan, pikiran, gagasan, atau ide itu dan format bahasa yang digunakan untuk menyampaikan atau mengemas pesan, pikiran, gagasan, atau ide itu. Terkait dengan format bahasa tersebut, teks dapat diungkapkan ke dalam 
berbagai jenis, misalnya deskripsi, laporan, prosedur, eksplanasi, eskposisi, diskusi, naratif, cerita petualangan, anekdot, dan lain-lain.

Terdapat perbedaan antara satu jenis teks dan jenis teks lainnya. Perbedaan dapat terjadi, misalnya, pada struktur teks. Sebagai contoh, teks deskripsi dan teks prosedur memiliki struktur yang berbeda, meskipun kedua teks tersebut termasuk ke dalam kategori teks faktual. Struktur teks membentuk struktur berpikir, sehingga di setiap penguasaan jenis teks tertentu, siswa akan memiliki kemampuan berpikir sesuai dengan struktur teks yang dikuasainya. Bahkan, satu topik tertentu dapat disajikan ke dalam jenis teks yang berbeda dan tentunya dengan struktur berpikir yang berbeda pula. Hanya dengan cara itu, siswa kemudian dapat mengonstruksi ilmu pengetahuannya melalui kemampuan mengobservasi, mempertanyakan, mengasosiasikan, menganalisis, dan menyajikan hasil analisis secara memadai.

Langkah-langkah pembelajaran yang dilaksanakan dalam penelitian ini menggunakan empat langkah seperti yang disampaikan oleh rose dan martin. Pembelajaran berbasis teks, terdapat empat tahap yang harus ditempuh (Rose \& Martin, 2012 dalam Dr. Tri Wiratno, M.A. 2013), yaitu: (1) tahap pembangunan konteks, (2) tahap pemodelan teks, (3) tahap pembuatan teks secara bersama-sama, (4) tahap pembuatan teks secara mandiri. Keempat tahap itu berlangsung secara siklus. Guru dapat memulai kegiatan pembelajaran dari tahap mana pun, meskipun pada umumnya tahap-tahap itu ditempuh secara urut. Selain itu, apabila kegiatan pembelajaran mengalami kesulitan pada tahap tertentu, misalnya pembuatan teks secara bersama-sama, guru boleh mengarahkan siswa untuk kembali kepada tahap pemodelan.

\section{Siklus I}

Pada saat siklus 1 siswa sudah menampakkan perkembangan hasil tulisan teks eksplanasi tersebut. Hanya saja siswa masih terpaku pada struktur dan mekanik teks saja. Unsur kebahasaan dan kalimat masih terabaikan termasuk isi teks. Bahkan pada hasil tulisan secara berkelompok maupun individu masih banyak yang menulis kembali kalimat-kalimat yang sudah ada dalam teks saja. Dalam hal ini ide dan gagasan siswa menjadi tidak terlihat.

Pada saat bekerja kelompok dan mempresentasikan hasil diskusinya ke depan kelas, siswa sudah memperlihatkan sikap bertanggung jawab dan saling menghargai antarsesama. Para siswa sudah menunjukkan sikap berani untuk mengemukakan pendapat. Hasil penulisan teks eksplanasi siswa belum menampakkan target yang peneliti inginkan. Oleh karena itu, berdasarkan beberapa kendala yang ditemukan pada siklus 1, maka penulis Pada saat masing-masing siswa tampil, kemampuan membacakan teks eksplanasi dengan media gambar berseri tidak memenuhi target peneliti yang seharusnya mencapai 65\%. Dengan ditemukan beberapa kendala tersebut perlu diadakan pembenahan-pembenahan. Menulis adalah menyampaikan ide atau gagasan dan pesan dengan menggunakan lambang grafik (tulisan). Tulisan adalah suatu sistem komunikasi manusia yang menggunakan tanda-tanda yang dapat dibaca atau dilihat dengan nyata. Tarigan (dalam Agus Suriamiaharja, 1996: 1), mengemukakan bahwa "Menulis adalah menurunkan atau melukiskan lambang-lambang grafik yang menggambarkan suatu bahasa yang dipakai oleh seseorang, sehinga orang lain dapat membaca lambang-lambamg grafik tersebut kalau mereka memahami bahasa dan gambaran grafik tersebut “.

Sedangkan Robert Lodo (dalam Suriamiaharja, 1996 : 1) mengatakan bahwa "Menulis adalah menempatkan simbol-simbol grafik yang menggambar-kan suatu bahasa yang dimengerti oleh seseorang, kemudian dapat dibaca oleh orang lain yang memahami bahasa tersebut beserta simbol-simbol grafiknya". Jadi menulis adalah kemampuan seseorang dalam melukiskan lambang-lambang grafik untuk menyampaikan ide atau gagasan yang dapat dimengerti oleh orang lain.

Teks Eksplanasi adalah jenis teks yang menjelaskan hubungan logis dari beberapa peritiwa. Pada teks esplanasi, sebuah peristiwa timbul karena ada peristiwa lain sebelumnya dan peristiwa tersebut mengakibatkasn peristiwa yang lain sesudahnya (brainly.co.id. 15 Januari 2014). Teks eksplanasi bertujuan untuk menjelaskan mengapa dan bagaimana proses terajadinya sesuatu secara alamiah atau proses bekerjanya fenomena alam maupun sosial.

Ciri-ciri teks eksplanasi 1) Strukturnya terdiri dari Pernyataan Umum merupakan gambaran awal tentang apa yang disampaiakan dengan pernytaan yang bersifat umum. Deretan penjelasan (eksplanasi) merupakan inti penjelasan apa yang disampaikan dan interpretasi yang berirsi pandangan atau simpulan penulis bersifat opsional, 
2) Memuat informasi berdasarkan fakta (faktual), 3) Faktualnya memuat informasi yang bersifat keilmuan/sain (http: Indahnya Bahasa Indon cerpennesia, Rabu, 12 Maret 2014).

\section{Siklus II}

Setelah diketahui bahwa siswa masih meiliki kelemahan berkaitan dengan isi, kosa kata dan kalimat dalam penulisan teks eksplanasi, maka diupayakan untuk membuat tulisan mereka lebih baik. Diupayakan agar anggota kelompok lebih aktif menggali informasi yang terdapat dalam gambar berseri yang ditampilkan. Gambar berseri yang dipilih berkaitan dengan tema peristriwa yang mereka alami langsung Pemilihan tema ini ternya mendukung terciptanya id dan gagasan siswa dalam menulis teks eksplanasi. Siswa menjadi tertarik mengungkapkan mengapa dan bagaimana proses terjadinya peristiwa yang mereka alami. Hasil akhir berupa penilaian kemampuan menulis teks eksplanasi dengan media gambar berseri diperoleh nilai yang melebihi target peneliti. Dengan demikian, hasil yang diperoleh sudah sesuai dengan harapan penulis. Secara keseluruhan analisis data baik siklus I maupun siklus II adalah sebagai berikut:

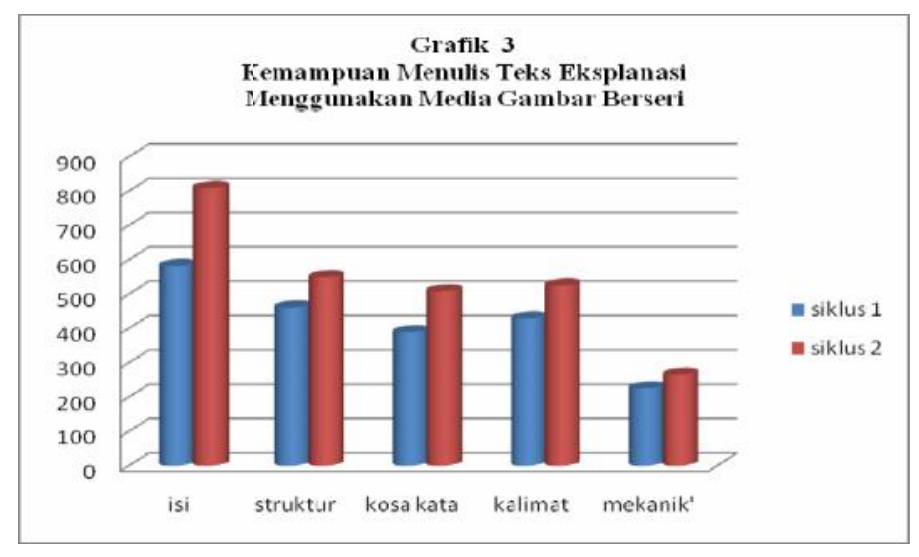

\section{SIMPULAN DAN SARAN}

Berdasarkan hasil analisis data dan pembahasan maka dapat disimpulkan bahwa penggunaan media gambar berseri cukup signifikan meningkatkan kemampuan menulis teks eskplanasi siswa. Siswa menjadi lebih terpancing mengeluarkan ide dan gagasannya. Apalagi gambar berseri tersebut menampilkan rangkaian gambar peristiwa yang baru mereka alami.

Saran yang dapat diberikan berkaitan dengan penelitian ini adalah (1) guru harus memaksimalkan latihanlatihan menulis teks eksplanasi. (2) Membuat jadwal kegiatan ekstrakurikuler di sekolah dalam kegiatan apresiasi khususnya menulis. Kegiatan ini menjadikan mereka terlatih mengemukakan idenya ke dalam berbagai bentuk tulisan, sehingga dapat mengembangtumbuhkan bakat siswa.

\section{DAFTAR RUJUKAN}

Abdurahman, Mulyono. (2003). Pendidikan Bagi Anak Berkesulitan Belajar. Jakarta : Depdikbud dan Rineka Cipta.

Arikunto, Suharsimi. (1997). Prosedur Penelitian Suatu Pendekatan Praktek. Jakarta: Rineka Cipta.

Arsyad, Azhar. (2002). Media Pembelajaran. Jakarta: Raja Grafindo.

Muhajir, Noeng. (1997). Pedoman Pelaksanaan Penelitian Tindakan Kelas Bagian Keempat : Analisis dan Refleksi. Jakarta : Ghalia Indonesia. 
Badawi, Ahmad. (1985). Kelompok Belajar sebagai Teknik Bimbingan dan Penyuluhan Metode pengajaran. Yogyakarta: Penerbit FIP-IKIP.

Suriamiharja Agus, M.Pd, dkk. (1996 / 1997). Petunjuk Praktis Menulis. Jakarta: Depdikbud.

Sabarti Akhadiah. (1996 / 1997). Menulis. Jakarta: Depdikbud.

Tarigan, Djago. (1996). Membina Keterampilan Menulis Paragraf dan Pengembangannya. Bandung: Angkasa. 